\title{
I Shout, Therefore I am an Energy: Bachelard and Capoeira Angola, A Phenomenology of the Body
}

\author{
Kafure da Rocha G* \\ Federal Institut Sertão Pernambucano (IF Sertão - PE), Brazil
}

*Corresponding author: Gabriel Kafure da Rocha, University of Rio Grande do Norte (UFRN) / Capes Pro-Doutoral, Rua Fera Ferida, n 40, Encantos de Igarassu, Brazil, Tel: +5587996601221; Email: gabriel.rocha@ifsertao-pe.edu.br

\section{Research Article}

Volume 2 Issue 3

Received Date: August 12, 2019

Published Date: September 23, 2019

DOI: $10.23880 /$ phij-16000127

\section{Abstract}

The present article intends to analyze the possibility of a dialogue between Bachelard, Capoeira and phenomenology of the body - how to reconcile European and Indo-African-American philosophy? To this end, we will use the imagery of Capoeira Angola in search of exchanges in this circle of knowledge. Bachelard's concept of physiognomony will be applied to Capoeira Angola to reveal the relation between animality and dissimulation in the imagery of this practice. Therefore, we will develop this complex using the force of antagonisms of poetics and epistemology. To this end, we will use brief comments by Hountondji and Senghor to unveil pluralism in Bachelard's French philosophy applied to Africanness and from this thinking experience seek to mediate accounts of native philosophical and geopoetic experiences as a teacher of Capoeira Angola and philosophy.

Keywords: Physiognomony; Dissimulation; Animality; Lautréamont

\section{Introduction}

\section{"Je danse, donc je suis."} Leopold Senghor

Iê!

It is with this ancestral shout that the experience of transforming movement into thought begins. This attempt is precisely the event of a soul that sings, dances, and is "flesh, the bios that shouts. It is non-Cartesianism taken to the extreme: '...je crie donc je suis une énergie'" -Ternes (p. 72).
Capoeira is the science of the body. Bachelard perceives the body as a complex structure of muscles and feelings ${ }^{1}$.
${ }^{1}$ In research for my thesis, I affirmed that we can also understand that this assertion would lead us to a phenomenology of the senses where feeling (heart) would permeate our rational perceptions of touch, taste, smell, sight, hearing, and the very intuition of a sixth sense. And by intuition as well one notes the discontinuity of the second phenomenology, whereas as an epistemologist, Bachelard is a harsh critic of intuition. Curiously, we can establish a main correlation between the senses and psychoanalysis in that "Did Freud not say that the superego is an acoustic influence (whereas the "id" may by natural or visual)?" (LESCURE, 1983, p. 199). Making use of this logic, we may deduce that the ego is then the sense of touch and for this reason, hearing, vision, and touch are the main active sense for Bachelard. "Smell is, truly, the most passive sense, the most earthly, the most immobile, the most immobilizing, that which, most slowly, most patiently, and most calmly, waits for imposed reality to distance itself, turn itself off, in order to then 


\section{Philosophy International Journal}

Firstly, the body of a capoeirista, is manifested phenomenologically in his or her story, starting with childhood, and it is cognitively read with the body. From all the scars and games that an Angoleiro (a person who practices Capoeira Angola) has acquired during his or her life, he or she may even mirror his or her master's idiosyncrasies, but what happens in his or her body is, essentially, fruit of self-awareness.

\section{Lautréamont's Animality and Capoeira Angola}

Seeking to understand ontogenesis of the body, I found in Gaston Bachelard not only a means of concretizing my thought in his alchemy with goes from epistemology of self to poetry, but also a means of translating my desires into metamorphoses. Thus, I transform into will an approximation between Bachelard and Capoeira. With this sentence, the present essay begins with the complex of bestiary and animality based on Bachelard's work Lautréamont which pays homage to the Songs of Maldoror $^{2}$. Even though it is a work of literary criticism, Bachelard inaugurates a new way of thinking about the body, and this is what most interests me in emphasizing my ability to transform thought into movement. Thus, I appropriated this poetic structure and inserted it into the circle of knowledge. A capoeirista's body need not by strong, but rather cunning, agile, and flexible, and this expertise is derived from knowledge and awareness of muscles, which we may consider a numen of the phenomenon of movement, seen that it is the condition which makes flexibility, blows, and acrobatics possible.

Actively, awakening our muscular sympathies, we will comprehend what would be a pure hygiene. When we experiment the consoling effect of physical training of solely internal character, which seeks the purity of impulse, we will be able to enact a sort of central gymnastics that will free us from the concern of executing muscular movements, at the same time that it will provide us with the pleasure of choosing them -Bachelard (p. 65).

\footnotetext{
dream about it" (Bachelard, 1989, p. 87). Taste on the other hand is revealed in its multiplicity, either in flavor or in linguistic capacity. It seems to be both an active and a passive sense.

2"The poem The Songs of Maldoror reached Bachelard's hands through Roger Caillois. It was at a congress that took place in Prague, in 1934, where the philosopher met the young poet who, at that time, was only twenty years old. During the congress Bachelard and Caillois had long conversations and during one of them the poet suggested that the philosopher read Lautréamont's magnificent poem." (Bulcão, 2014, p. 89)
}

For this reason, the capoeirista's body is spiritually healthy. Capoeiristas must overcome corporal problems, as their ability to be elastic is constantly surmounting their armor, neuroses that become engrained in the physical posture they are get used to before the world. If a capoeirista has injuries, it is because he or she fell, and must for this reason get up, recognizing his or his limits and seeking to overcome them with self-physical therapy; going slowly or wondering he or she will succeed in curing him or herself. With this, it may be affirmed that the wisdom in Capoeira, more than in the game, is in wellbeing in terms of health. And in this sense, health is a healthy mind, a healthy body, a happy ginga, a smile, and a way of singing that spreads poetic magic and coordination of synchrony throughout the roda. Otherwise, when a capoeirista gets hurt, he or she will probably hurt the other, and this demonstrates a lack of self-awareness, when he or she uses animal bestiary and violently injures the other. Nevertheless, this must be a strategy of blocked energy to intimidate the opponent and to make one's own aura prevail within the roda.

In this sense, every movement of a capoeirista is a choice of freedom; instinct and destiny surround the trance of Capoeira. When a person does something that goes beyond that which his or muscles and intelligence calculated, it seems that the trance is elevated like a discovery of that which is beyond the body.

Without going very far, we may verify that instinct organizes and thinks. It maintains specified thoughts, desires, and wills long enough for these energies to materialize in the organs. The offensive instinct continues a movement with enough will for the trajectory to become a fiber, a nerve, a muscle-Bachelard (p. 30).

Here, then, is the question: in the roda and its spatial relation, it is necessary that two individuals endowed with the mastery of instinct are able to occupy their own place. That is why, in terms of training, it is essential that capoeiristas understand all the ways of making their bodies through movements, of inhabiting themselves and inhabiting places. When they have understood this, they successfully realize the transposition of being nomads, traveling the world in their bodies, playing, launching themselves, and living off of this.

This is truly extraordinary when it does not go to one's head as vanity. Here, the capoeirista's world is more than bohemia and the ability to play and come out victorious. To learn to play is to know how to lose, and the capoeirista's world is the ability to make his or her body inhabit his or her identity. I may thus say, in a certain sense, that the capoeirista's world is the sculpture of the 


\section{Philosophy International Journal}

self, both in the aspect of how the player is created, conceives him or herself, and is conceived by the master, and in the aspect in which he or she carves this image with the representation of his or her movements.

This instinct must promote a metamorphosis, and it is here that animality comes in. In Lautréamont, Bachelard begins his bestiary with repulsive animals, dedicating his reflections, firstly, "to the crab, the spider, and the frog" Bachelard (p. 23). These are the first examples. These animals-insects-crustaceans-amphibians represent shifting movements in Capoeira, the Angoleiro changing location on the ground. The "crab" movement is on of the most ancestral archetypes, also known as middle ginga. For Bachelard, the physiognomic characteristic of the crab is the fact that it "prefers to lose a leg than to let go of its prey. Its body has less volume than its claws. [...] we may express the crab's motto thus: we must live to grasp rather than grasp to live" -Bachelard (p. 32). The "spider" is the shifting movement related to the arms and hands, with one's torso facing up. It is a movement of defense, much like the "crab," which Bachelard likens more to a louse, whereas the spider is in the same archetype as the leech, the octopus. "We see here the old spider of the 'big species' that squeezes the throat of its sleeping victim with its fangs. Here we read the agony of the 'immense suction'" -Bachelard (p. 35). And the frog is the jumping movement that protects between the legs. Bachelard does not develop his thoughts on the frog, but he says that they are easily torn to shreds by dogs.

What I now find important is trying to decipher the greater archetypes of this animality. Which, in my opinion, never run out. Following the logic of the trilogy, I now classify the snake, the jaguar, and the hawk as the principle arcana of instinctive animality in Capoeira. "Here, however, once more, we had to recognize that the traditional cruelty represented by the tiger or the wolf had no dynamic value. The image of the tiger, with its classic cruelty, would soon block the complex" -Bachelard (p. 25). The black jaguar that disguises itself into night hides itself almost as well as the snake; at night only its eyes shine.

The snake, the great mother, with its circular movement that symbolizes Capoeira's roda, is the animal of the earth, that transits between the mineral and vegetable kingdom, a living plant. The jaguar is the symbol of freedom. It moves freely from the paths of the vegetable kingdom, but it is the very force of the animal kingdom as it inhabits forests and faces the violence of the world. Regarding these animals, Bachelard says, "The former moves with the steps of a dancer, the latter with a tiger's leaps!" And the hawk, finally, is the vision of possibility on the horizon of the human kingdom, "The eagle, much like the louse, or the crab, and all the animals vigorously imagined in the bestiary, may change dimensions" -Bachelard (p. 34).

Mestre Pastinha said that he had two disciples, one a tame snake and the other a hawk. Or be it, the connection between the earth and the sky, a co-belonging. That notwithstanding, it is in the snake, as a symbol of selfawareness, when it bites its own tail, that the world of Capoeira is delimited. For Bachelard, more than a tail, the snake is an arm, "the snake is a flexible arm, it is agility" Bachelard (p. 36).

To go down another path, I would like to comment on Capoeira as a phenomenology of the self, in this case, as an Afro-descendant philosophy that is constantly demonstrated in my vision of capoeira. For me, Mestre Pastinha really was the center from which Capoeira Angola radiated to achieve the metaphysics of Capoeira. However, it is possible to go deepen yet into the "being of Capoeira," given that both being and capoeira are infinite. And the process of creation, deconstruction, and even destruction as well: everything depends on the circumstance, and this ephemerality is fundamental in the corporal epistemological construction of the phenomenon of Capoeira.

This knowledge must be filtered through the scientific method which, according to Bachelard, is a method of "circumstance." The African researcher must, thus, integrate what Patimale José Blaunde call the dynamic of "creative destruction." In other words, two fundamental principles must inhabit African mentality: rupture and demarcation -Ogou (p. 54).

Here we come to the circumstance of mastery, in which the master is the greatest learner, for he or she constantly deconstructs the self in order to reconstruct his or her disciples' knowledge of the body. With the ability to imagine, to invent, to deal with errors, and to teach the "no" in the broad sense of the term, the master is the father, the one who, first and foremost, via a feeling of friendship develops learners' ability to find their being through Capoeira. The master is the one who holds the teachings and these teachings may often be denied by the disciple, in a parricide that, at the right time, the teaching that sprouted and matured in the disciple, has become the very capacity to understand the time for everything and to know the right time to harvest fruit; herein lies the mastery of the master. Angoleiros must know themselves, must know how far the limits of their world extend and, if necessary, become counter-masters; or be it, questioning 


\section{Philosophy International Journal}

and bringing about a rupture is something that is part of the discontinuity of their animality.

"The debate in question here is this: the spectacle of the animal sometimes hypnotizes us to the point that it inspires us toward inhumane conduct: how to discard, how to psychoanalyze this obstacle that frustrates our human vocation" -Mansuy (p. 30). The human vocation is thus revealed in the capacity for physiognomony and the overcoming of obstacles; here it is necessary to be attentive to the gnomy, to the knowledge that is unveiled of the physio. It is here that we enter the methodology we want to get at, where the circumstances that we are, as Ortega y Gasset would say, unfold in pluriverse situations.

Our present society is, truly, an original society, economically and culturally heterogeneous, with African, [Indigenous], and European contributions. In Le Nouvel Esprit Scientifique, Gaston Bachelard observes, quite appropriately, that a new method is always necessary to face a new situation. This is our case-Senghor (p. 102).

By physiognomony we may then understand that method of unveiling this social-individual simulacrum that permeates the surface of the face ${ }^{3}$. The difference between Bachelard's physiognomony and physiognomy as it is commonly understood is that, while the latter aims to reach the interior of the individual, the former aims precisely at undertaking a phenomenology of the dissimulation of superficialities. And thus to explore the process of images that create the self and the imaginary.

Physiognomony is the contraction of facial muscles, and, in turn, the creation of masks, or "bad faces" A process of exteriorization that is spontaneous and inherent to all primitive cultures around the world, exorcizing their animality.

In this sense, for Bachelard, the decisive features of physiognomony should be sought in the face that is revealed in the form of a mask [...], because this is the result of an imagery process of creation which reveals what the individual is intimately. The virtual masks are, thus, psychological masks; we learn them through our interpretations. It may by said that virtual masks assume

\footnotetext{
${ }^{3}$ The lines of the face, "Faced with such an animalized human face, we feel a certain satisfaction. Will we be content if we dominate the animal the we recognize in it?" (Bachelard, 1989, p. 98). The difference or perhaps the similarity between the concept of Face in Bachelard and Levinas is that, while for Bachelard it is the awareness of animality in a person, for Levinas it is the sense of awareness of exteriority; it is not merely the sum of its features and parts but rather its own alterity.
}

our decision of having a physiognomony; they are, in reality, spoken faces -Bulcão (p. 54)

The desire to have a physiognomony is very similar to the capoeirista's process of separating or not from the master-father. This is where the phenomenology of dissimulation unfolds as the source of his or her art and technique develops. It is possible to say then that the root of the physiognomony, found in Lautréamont and his animal bestiary, through the interpretation of Bulcão, opened an important trail to us.

Note what Bachelard himself had stated:

Could we develop these explanations further, we would arrive at the conclusion that physiognomony, in its anatomical descriptions, completely forgot the temporal features of the face. We will find these temporal features reliving the dynamic of gestures in its complex synthesis, distinguishing the different energetic phases and, above all, establishing the just nervous hierarchy of multiple expressions. The face of a decided man reveals the instants of mutilation of his being. Common sense is so little observant that it confuses all its observations under the simple signal of an energetic face-Bachelard (p. 89).

In Capoeira Angola, individuals endeavor to find their animal archetype, their name, but they do not know that the idea of the animal is an archetype that seeks the face of the deepest phobias that pervade our unconscious. After finding their Shamanic totem, Angoleiros find in their path their own Orisha, as a sublimation of this animal side. For Bachelard, the animal is a monovalent psychism, so that it is not a machine, but a monomania of a machined animality that discovers instinct. Thus, Bachelard's method unveils three phases applied to Capoeira: from the insect (movement) - to the animal (physiognomony-knowledge) - and finally to the Orisha (spirituality). These three phases are not exclusive or linear, in the evolutionary sense; they are more like states that rotate around themselves. Some capoeiristas never make the leap from one to another, while others succeed in living all of these aspects and find full mastery.

One does not mean the spontaneous development of traditional wisdom in modern episteme, but rather the involvement of the former in the latter, as Bachelard would say. On this topic, the correct execution of this project of involvement (integration, recovery, etc.) presupposes the elaboration of a methodology that might not be exclusive to scientists, but would also include philosophers -Hountondji (p. 100).

In this philosophical sense, Bachelard believes that there is equality between animal conduct and human 


\section{Philosophy International Journal}

myth, in a diverse function of classical parallelism between instinct and intelligence, and, for this reason, human instinct has an appetite for forms which are the same as that of matter. In dynamizing principles, humans seek the reality that the animal is a fundamental principle. "At that point, devouring is more important than assimilating; or rather, only what is devoured is assimilated" -Bachelard (p. 118).

In this anthropophagy, passive and active in its tastes, in the palate of its speech, aggressive animality occurs through unpredictability. Like in the world of insects, it is present in the butterfly or even the hummingbird, the same sense of attacking the flower, regardless of the gestures' impact or lightness.

Finally, through this awareness of animality we may say that "Capoeira for the harmony of being," one of the phrases my master taught me, after so much struggle of self against self, against nature, against the world, fulfilled in its teaching, is the harmony of the self, the harmony of being someone with something to play in the game of exchange of knowledge. The philosophy is that every learner has potential and virtues to be developed through capoeira; it is not only the virtue of the game, the song, and the movement. It is in training that the master demonstrates that movement is more than throwing one's legs into the air. Capoeira, emphatically, is to see the world upside down, and that means seeing things as they really are and deconstructing them. Note that many masters do not wish to teach their greatest secrets, their tricks, and therein lies a big difference between the old Capoeira (in which I did not truly participate but have heard tell from my predecessors). In the past, one had to grow in order to be ready to learn the value of everything, whereas today a lot is sold, but Capoeira, in essence, sells nothing of itself; it is learned by watching and observing. The masters of the past took their students by the hand and taught, always maintaining elegance and respect, for this is the condition of civility, the piety of their devotion, their ceaseless work of resignifying themselves and showing the being of capoeira. Those who do not have respect and knowledge, it is because they could not see the limits of his world and did not find themselves.

The movement of the body is born in the relation between prediction and imagination. To build one's body, to be a thinker in movement, it is necessary to be constantly connected to the instant "in which metamorphosis reveals the complete game of being" Bachelard (p. 121). Thus, we wish to say that this involvement of the ancestral with contemporaneity and current scientific thought is not often down owing to the negation of laziness. But when we say that philosophy is the result of idleness, laziness thus reveals the translation of this impulse of dissimulating thinking, a function found even in the animal kingdom, but also in the gesture of mammals when they yawn and perhaps even dream.

"This deformity does not translate that strange movement of one who stretches lazily to its opposite; the relaxation produced by an internal tightening that causes the body to swell due to laziness is known to be ephemeral and harmless" -Bachelard (p. 102). Dissimulation is that which you wish to hide; it is the very being; it is that which, in its simulation is a simulacrum that creates a new surface in the face of things. This phenomenology seeks to "return to the root of the will to be other than what one is" -Bulcão (p. 49). And this is an impulse of will and desire that is present in everyone, that can only be found in the self, because if it is seen in another it ends up interpreting a simulation. To dissimulate is to unfold the self from oneself.

\section{Conclusion}

We can see that the thought experiment of bringing a work of literary criticism like Lautréamont de Bachelard closer to a reality phenomenon such as capoeira could generate a philosophical and aesthetic experience of a new worldview. A final point to note is that the deformation of images must be strictly mathematical. It should also be noted that the mathematical influence on Bachelard in his reading of Lautreámont also brings a critique called the syntax of images, by which the operation of metaphors is organized in such a way. To find the metric of a projective poetry, a primitive poetry that creates its own language, as it promotes a singularity that must rebel and discard books and masters.

Capoeira consists of this primitive and poetic manifestation of the body as dance, fight and game, but its hierarchy ends up in order to self-preservation, while our reflection shows that the break with this structure is fundamental for artistic creativity. That is why the model of capoeira angola is preserved by ancestry, although the artistic potential of this phenomenon can only be the result of poetic, philosophical and even anarchic freedom and this can be very beneficial for the creation of new meanings even for traditional knowledge.

\section{References}

1. Bachelard G (1989) Lautréamont. Trad. Maria Isabel Braga. Lisboa: Litoral Edições. 
2. Bulcão M (2011) A máscara e o rosto: dissimulação e verdade as perspectivas de Gaston Bachelard e François Dagonet. Ideação 1(25).

3. Bulcão M (2014) Bachelard diante do onirismo dinâmico e visceral de Lautréamont. IN: Almeida Fábio (org.), Tempo de Lautréamont. Goiânia: Ricochete, pp: 86-103.

4. Hountondji P (1996) African philosophy - Myth and Reality. 2 ${ }^{\text {nd }}$ (Edn.), Henri Evans. Indiana: Indiana University Press.

5. Lescure J (1983) Un Été Avec Bachelard. Paris: Luneau-Ascot.
6. Ogou V (2018) Gaston Bachelard et l'Afrique - Pour une psychanalyse de la connaissance africaine afin d'amorcer le développement sur le continent africain. Paris: Edilivre.

7. Mansuy M(1965) Bachelard et Lautréamont, I : la psychanalyse de la bête humaine. Études françaises 1(1): 26-51.

8. Ternes J (2014) Bachelard e Lautréamont: Literatura, primitividade, animalidade. In: Almeida F (Ed.), Tempo de Lautréamont. Goiânia: Ricochete.

9. Senghor L (1965) Um caminho do socialismo. Trad Vicente Barretto. Rio de Janeiro: Ed. Record. 